\title{
Extending ethnic humour theory: Genuine vs. functional ethnic joke scripts
}

\author{
Aleksandar Takovski \\ South East European University \\ a.takovski@gmail.com
}

\begin{abstract}
Most ethnic humour that has been studied so far consists of jokes which use ethnically nonspecific qualities such as stupidity or canniness in order to ridicule an ethnic group and thus to preserve and perpetuate ethnically based social hierarchies in western industrial societies. In light of this dominant logic in ethnic humour theory, the objective of this study is to problematize the relation of such non-ethnic qualities and the notion of ethnic identity, as well as their relation to a specific type of society, in an attempt to convincingly argue in favour of the need to differentiate between 'ethnically-empty' functional joke scripts and genuine ethnic joke scripts that are related to the ethnic identity of the target. In so doing, I extend ethnic humour theory by introducing and testing the notion of genuine ethnic joke scripts in order to motivate future research that will tackle other potential ethnic humour idiosyncrasies. Toward this end, I have collected and analysed joke material $(N=369)$ coming from Macedonia, Bulgaria, Serbia, and Albania, societies with histories and relations very different that those in the western industrial societies. Additionally, the study incorporates two questionnaires with members of the two largest ethnicities in the Republic of Macedonia, Macedonians and Albanians, to ascertain the relation between the genuine ethnic humour and ethnic identity.
\end{abstract}

Keywords: ethnic humour, genuine and functional ethnic scripts, Macedonia, ethnic identity.

\section{Turbulent ethnic history, troublesome multiethnic society, genuine ethnic humour}

Macedonian history, overwhelmed with ethnic and national conflicts and contradictions and Macedonian modern multiethnic society burdened by recent ethnic clashes between the two largest ethnic communities, Macedonians and Albanians, are undeniably rich terrain for interethnic humour to emerge. The turbulent $19^{\text {th }}-20^{\text {th }}$ century of Macedonia, marked by unsuccessful attempts at nation and state formation at the turn of the 20th century and the subsequent submersion of its territory and population within the nation states of its neighbours (Greece, Bulgaria, and Serbia), as well as the antagonism between them, have all been reflected in the Macedonian neighbour' nationalist discourses, both serious and 
humorous. Unlike the ethnic humour of Macedonian neighbours which ridicules genuine identity markers. In a different way, the multiethnic structuration of modern Macedonian society has resulted in the construction of types of humour that are less marked by ethnicity. In this respect, the different historic, political, and social roles and relations between ethnic Macedonians and ethnic Albanians in Macedonia-Macedonians being the socially and politically dominant group in the Yugoslav and the post-Yugoslav period-have contributed to the construction of two different types of ethnic humour. The Macedonians' ethnic humour on Albanians is that of the dominant social group typically ridiculing the ethnic minority for its linguistic and behavioural ineptness, in an attempt to preserve the social hierarchy (Kuipers \& van der Ent 2016). Albanian humour in turn is not so much a subversive form of resistance, although such examples can be found, but more a form of self-disparagement, self-criticism, and survival. More importantly, the lack of wider social contact and cohesion between the two groups has resulted not only in the social, cultural, and political parallelism between the two groups but also parallelism in and ignorance of each other's humour.

The key objective of the study is to use the historic and political rootedness of ethnic humour on Macedonians in order to raise and discuss some theoretical and conceptual questions regarding the problematic definitions and understanding of the notions of ethnic humour and ethnic scripts and their relation to the notion of ethnicity and ethnic identity. It has been generally accepted that ethnic humour is a type of humour that ridicules traits of different ethnic groups. However, while some authors have accepted (Apte 1987; Weaver 2014), or at least have done declaratively so, that such traits (behaviour, customs, traditions) are closely related to the specific sociocultural identity of the joke targets, the analysis of the ethnic humour has largely relied on jokes that operate on universal traits such as stupidity, laziness, canniness, popularly termed as ethnic joke scripts. While ethnic humour relying on such non-specific traits has great social and political power to perpetuate ethnic based social relations and structures, the scripts themselves are not constitutive of the ethnic identity of the ridiculed group as they do not relate to what research on ethnicity has termed as identity markers, referring to the ethnically idiosyncratic, distinguishing qualities such as kingship, language, religion, customs, ancestry, and shared history, which define the contents and the boundaries of ethnic groups.

Whether the identity markers are theoretically understood as cultural 'givens' (Geertz 1963), commodified political resources by which appeals to large audiences are made (Brass 1991) and benefits of joining ethnic organizations promised (Hechter 1986), mechanisms of alignment (Cohen 1996) or instruments of inter-ethnic differentiation (Barth 1969; van den Berghe 1995) their status as elements defining ethnic identity remains unaffected. One definition of ethnicity (ethnic identity) merging several of these parameters is provided by Anthony Smith, for whom an ethnic group is "a type of cultural collectivity, one that emphasizes the role of myths of descent and historical memories, and that is recognized by one or more cultural differences like religion, customs, language, or institutions" (Smith 1986: 32; 1991: 20).

Conceiving ethnicity as a historically constructed idea of belonging to a collective by way of sharing common ancestry, myths of origin, historic memories, language, tradition and customs, would lead to the logical expectation, as I have argued elsewhere (Takovski 2015), that ethnic humour should be a derisive, or at least teasing, contestation of the ethnic identity markers. In other words, targeting identity markers such as ancestry, history, language, customs, by using them as joke scripts, would be a form of genuine ethnic humour. But the existence of such scripts have not yet been duly registered and discussed. Identification of such scripts would mean that the ethnic humour theory in its present state, could beneficially integrate a slight revision, a novel taxonomy as to accommodate such findings. In this respect, this study is a pioneering initiative to test the possibility and legitimacy of differentiating 
between two types of ethnic joke scripts with the hope of making a novel contribution to ethnic humour theory. If such scripts can be identified, I argue, then one should be able to differentiate between functional ethnic humour and genuine ethnic humour in an empirically validated fashion. The former type, which has already been the subject of much research, refers to humour that uses universal scripts such as stupidity and canniness to preserve ethnically based social hierarchies and power relations in western, industrial societies. The latter type of humour uses scripts that are more closely related to the notion of ethnic identity and its (primary) function is not to perpetuate social hierarchies, but to express and even perpetuate inter-ethnic, historically constructed antagonisms that serve to maintain ethnic boundaries. Such is the case, I argue, with Bulgarian jokes on Macedonians by which Bulgarians do not regulate ethnic based social hierarchies, but rather express sentiments of superiority and historically based antagonism.

To argue convincingly in favour of the necessity and legitimacy of making difference between genuine ethnic humour and functional ethnic humour, and thus to achieve the goal of demonstrating the existence of genuine ethnic joke scripts, I have gathered joke material from four Balkan states (Bulgaria, Macedonia, Albania, and Kosovo). The first objective is to identify scripts that rely on ethnically defining parameters like language, customs, history that can be discursively evidenced in history, talk, perception, and memory of the members of the ethnic groups, while the second objective is to examine and discuss their relation to the ethnic identity of the targeted group by registering (inter)ethnic perceptions of the relation between the joke scripts and the ethnic identity of the target.

To accomplish these objectives, the following methodological procedure was undertaken. First, internet ethnic jokes corpus $(\mathrm{N}=369)$ was created by collecting samples from several internet sites $(\mathrm{N}=13)$. The samples were then categorised into ethnic jokes about Macedonians $(\mathrm{N}=256)$ and ethnic jokes about Albanians $(\mathrm{N}=113)$, a corpus collected and organized by the help of two informants, ethnic Albanians. The two corpora were further broken down into jokes with functional $(\mathrm{N}=196)$ versus jokes with genuine ethnic scripts $(\mathrm{N}=173)$. Out of two ethnically based and organized corpora, six samples from each were selected and used in the two online questionnaires conducted with the members of the two ethnic groups respectively. The aim was to register and measure respondents' perceptions of the relation between ethnic scripts and ethnic identity.

\section{Ethnic humour}

Ethnic humour is a complex phenomenon generally referring to the process of ridiculing an ethnic other. However, a singular definition, or a consensus about the motives and the ends of such humour seem difficult to reach. The ethnic varieties around the world are too great and complex to be plausibly accounted by a single definition. However, the problem with the existing definitions is that most of them rely on behavioural qualities that are unrelated to ethnic identity. In the light of this claim, some theoretical concepts and research findings need to be revisited as to accomplish two goals. First, by providing an overview of some seminal ideas the discussion will sketch the theoretical framework of the study, while at the same time it will try to critically contribute to the body of literature by addressing some conceptual shortcomings.

\subsection{Ethnic humour, joke scripts and targets}

The most common denominator of any definition of ethnic humour is the ridicule of the ethnic other. For Apte (1985: 115) it is a type of humour in which "fun is made of different 
traits of a group and/or its members thanks to their social, political, cultural, religious and economic background"; for Schultz ethnic humour is an "invective humor directed at racial and nationality groups, denigrating alleged attributes of those groups" (1989:167); and a more recent definition by Gonzales and Wiseman explains that ethnic humour is phenomenon in which "one culture seem superior by comparing or making fun of idiosyncrasies of other cultures including dialect and traditions." (Gonzales \& Wiseman 2005: 173.) There is no doubt that ethnic humour portrays an asymmetrical relation in which the joker manifests his superiority through a ridicule directed towards a specific ethnic group. The problem is not who is being laughed at, but how. The target of ethnic humour is always an ethnic group, but its contents, as studied so far, is rarely, if ever ethnic. Despite authors' recognition of ethnic identity as related to specific, idiosyncratic traits, most of the analysed material are jokes that portray the targets in a rather universal, non-ethnic manner. In Apte's own words, the most common ethnic jokes tend to portray the target ethnic group as "stupid, ignorant, or unclean" (Apte 1985: 115).

In a similar fashion one of the most prolific authors on the subject of ethnic humour, Christie Davies, explains that the central theme of ethnic joking is "pinning of some undesirable quality on a particular ethnic group in a comic way or to a ludicrous extent" (Davies 1990: 4). Despite the great number and variety of ethnic groups throughout the world, the number of these qualities as Davies' work has shown is very low $(1990 ; 1998)$. The two most frequently occurring such qualities, also termed joke scripts, are stupidity and canniness, and their ascription is guided by implicit cultural rules. The script of stupidity for example is regularly distributed along a centre-periphery axis in which the social majority which occupies the centre and defines acceptable norms and values pins this quality to the marginalized ethnic minorities occupying the societal periphery in an attempt to perpetuate an ethnic based hierarchy (Kuipers \& Ent 2016), or to preserve social normality (del Rio 2013). The rules underpinning the ascription of this script, as laid out by Davies, state that targets are people who live on the periphery of the joke tellers, are perceived as culturally ambiguous, backward, and provincial people with strange archaic customs. Most often these are rustic people, or immigrants in search of unskilled and low-prestige manual work, or close neighbours and ethnic groups who have historically shared the territory and who share the same cultural background or even speak a similar or identical language with the joke tellers. Additionally, these are often people who have failed to succeed in an open and competitive system.

Although these assumptions can be supported by a great number of jokes, there are some conceptual challenges throughout the theory. Number of studies have offered findings that do not easily fit into Davies's conceptions. Genova's study on Bulgarian humour (2011) has demonstrated how ethnic groups like Romani are never represented as stupid despite their status as a socially marginalized groups. In contrast, their marginalization is accomplished through other scripts such as 'thieves', 'liars', or 'unclean'. Genova has also shown (2014) how the opposition of stupid versus canny do not apply to Armenians, one of the two target of Bulgarian ethnic humour, who are represented in joke lore no differently than Bulgarians themselves. Popescu's study of the Romanian ethnic humour on Romani (2011) shows an ambiguous tendency of representing Romani as stupid and canny at the same time. Specifically discussing the script of stupidity, Liisi Laineste (2005) demonstrates the challenge that the Estonian material presents to some of the assumptions made by Davies, especially the assumptions on the rules and patterns governing the ascription of 'stupidity'. The material Laineste uses shows that some joke targets in Estonian jokelore do not easily fit into Davies criteria of stupidity script ascription, as is the case of the Chukchis (an indigenous population inhibiting the eastern-most area of Russia), who despite not sharing territory, language, or culture with the Estonians are the most popular targets of Estonian ethnic jokes. 
At the same time, the Estonian material poses a challenge to the claim that ethnic jokes are told downwards, since jokes in Estonia are made on ethnic groups higher up the social scale (e.g. Estonians about the Russians). Based on this evidence, Laineste rightfully observes that "Davies' generalisations which are mostly based on jokes in the Anglo-Saxon culture area and might apply to the ethnic humour of all countries fail to consider the possible political and historical idiosyncrasies between capitalist and socialist, closed and open, dictatorial or democratic societies" (2005:22).

Similar criticism can be levelled at the Dutch social anthropologist Giselinde Kuipers (Kuipers 2000; Kuipers \& van der Ent 2016) whose studies on ethnic humour in the Netherlands demonstrate that ethnic humour mirrors identity politics and reflects the relations between jokers and joke targets. Ethnic jokes help the social centre to perpetuate an ethically based social hierarchy by humorously marginalizing the ethnic and national minorities who are always presented as stupid, backward, dirty, criminal, poor, lazy and so on (Kuipers \& Ent 2016). The joke targets, according to Kuipers are different problematic immigrant ethnic communities with low socio-economic status who failed to adapt, and therefore are considered a threat (Kuipers 2000). The argument is resonant with Davies' view (1990) that the rise of the ethnic jokes, especially those based on the script of stupidity, stem from the rise of modernity, and the adherent processes of modernization and industrialization which necessitated 'imported' cheap labour immigrants only to be laughed at because they failed to adopt to the capitalist market logic. Following this logic one easily gets caught up into the assumption that "ethnic jokes flourish when a nation absorbs a large wave of immigrants who are unable or unwilling to assimilate rapidly. At such moments, ethnic jokes serve as agents of social control (Boskin \& Dorinson 1985:155; Davies 1990; Boxman \& Shifman 2015:522).

The problem here is not the validity of the conclusions, but the need to resist the challenge of generalizing them beyond the scope of capitalist industrialized societies. These societies, based on their own particular economic and historic contingencies, structure and organize social relations in specific manners different than those in other non-industrial, noncapitalist societies. No doubt the connection between modernity, industrialization, immigration and the ascription of stupidity to certain groups of people works well in the western societies. The challenge in this respect are the non-industrialized, non-capitalist societies, where the rate of immigration is much lower or non-existent. However, this does not mean that such societies do not ascribe stupidity or laziness to ethnic groups. Bosnians for one, the old time favourite targets of all ex-Yugoslav nations, have been targeted for stupidity prior and after the dissolution of Yugoslavia, although they have never occupied any periphery, nor were they immigrants or low wage workers. Very likely, the humour on them was deployed in order to make them appear socially peripheral without actually occupying such status in society. More importantly, the whole nexus of sociopolitical and historic circumstances in the Balkans is marked by neverending interethnic struggle, contestation and conflict represented, perpetuated and contested in variety of discourses, humour included. Thus unlike the material from the western societies - jokes operating on non-ethnic scripts that perpetuate social hierarchies - the material from the Balkans will hopefully show that there are inter-ethnic jokes between neighbouring countries that do not operate on stupidity scripts, but instead, are either based on scripts more closely related to ethnic identity, or are products of unique historic and political relations between the countries. As such, they do not enhance social hierarchies within a single society but instead, express and perpetuate identity related interethnic anxieties. The Balkan joke material, mostly joke lore ridiculing Macedonian will hopefully show this, and thus contribute to the ethnic humour theory with novel assumptions stemming from humour material and ethnic-historic circumstances that are different from the industrial, capitalist west. 


\subsection{Functions of ethnic humour}

One of the key functions of ethnic humour is to "define and redefine the boundaries of socially differentiated groups" thus demarcating 'us' from 'them' (Apte 1985: 55). This "enables members of an in-group to enhance their feelings of group identity and cohesiveness while excluding and emphasizing their differences from members of an out-group" (Martin 2007:18). Or as Sollors nicely explains "laughing at others is a form of boundary construction", adding that "the community of laughter itself is an ethnicizing phenomenon, as we develop a sense of we-ness in laughing with others" (Sollors 1986: 132).

But very often the humour which asserts superiority over a subordinated and ridiculed ethnic minority is adopted, reworked and turned back at the ridiculing majority. As Boskin and Dorinson explain, "the resulting derisive stereotypes were adopted by their targets in mocking self-description, and then, triumphantly, adapted by the victims of stereotyping themselves as means of revenge against their more powerful detractors (Boskin \& Dorinson 1985: 81). Thus, ethnic humour functions as a subversive means of liberation and a weapon of revenge against those in power (Boskin \& Dorinson 1985; Lowe 1986). This double edge functionality as means of an attack (ridicule) and a defence (weapon of liberation) is neatly captured in Rappoport's metaphor "sword and shield", who explains that "depending on its context, such humour can be offensive, aimed at ridicule of a stereotyped group; defensive, aimed at protecting the group from ridicule; or both" (2005: 1).

The conflict between ethnic groups can also be managed by using humour as a peaceful mode of lessening tension and hostility, and lowering fear (Lowe 1986; Schutz 1977, 1989). The idea is well captured by Schutz (1989) who contends:

that which is being aggressively ridiculed becomes familiar through its pleasurable exposure. It becomes subject to rational criticism, rather than prejudiced hostility. A feared "trait" of a rival ethnic group is treated as a laughable foible and, thereby, the in-group become [tolerant] of the foreign. In turn, the ethnic target of the humour is more acceptable in the larger society, and the minority group comes to see itself and the objectionable features of its behaviour in the light of the standards of the larger society.

(Schutz 1977: 259)

Although well explained, the idea that ethnic humour can promote rational criticism and tolerance is somewhat difficult to believe, especially in contexts where the nature and intensity of intergroup conflicts are such that humour may function more as an abrasive tool of conflict and boundary maintenance rather than social lubricant of fostering intergroup communication and acceptance (Martineu 1972). Given that ethnic humour is based on stereotypes and pinning down of negative qualities, it is a real challenge to find convincing empirical evidence that calling someone stupid, lazy, or sexually inept can lead to rational criticism, tolerance, and acceptance. In the end, making the ridiculed minority see its 'objectionable' character is far from a mode of interethnic tolerance and acceptance.

Perhaps, using gross and general stereotypes to mitigate interethnic tension, reduce conflicts, displace violence and aggression, and to lubricate everyday communication is possible in some multiethnic societies such as Hawai'i (Oshima 2000), where groups are ethnically mixed, and where people understand and respect each other's ethnic cultures and are sufficiently confident about them. In such multiethnic societies, people are able to express stereotypes with pride and even joy (Oshima 2000: 42). In such circumstances, the existence and use of healthy ethnic humor symbolizes peaceful ethnic relations and mutual respect. But Balkan societies are not societies of this kind, therefore these assumptions are difficult, if possible at all, to adopt. In this respect, it is expectable that the humour produced in the 
Balkans whose history is overwhelmed with instances of national conflicts and contestations, will to a certain extent manifest the underlying circumstances, acting more as a tool of conflict perpetuation than of lubrication and acceptance. Moreover, it is also conceivable that the perpetuation of these conflicts is aided by the proliferation of joke scripts that are ethnically insensitive, such that they widen the gap between the ethnicities by trodding on ethnically sensitive neuralgic spots of ethnic identity. This study seeks to identify and to provide a plausible account of their relation to ethnic humour.

\section{Data and methodology}

During the first procedure, two data corpora were created: jokes about Macedonians $(\mathrm{N}=$ 256), and jokes about Albanians $(\mathrm{N}=113)$. The samples were harvested from several Bulgarian, Serbian, Macedonian, and Albanian websites, all listed in the Appendix 1 (list of internet resources). The first three groups of resources provided jokes about Macedonians, while other three (Serbian, Macedonian, and Albanian sites) were used as resources to collect jokes about Albanians, a corpus collected and organized by the help of two informants. The aim of collecting these samples was to identify the truly idiosyncratic ethnic jokes with scripts that relate to ethnic identity markers. Identifying such scripts was first undertaken by the researcher and then double-checked with another coder (a colleague) who was briefed on the concept of ethnic identity markers and asked to single out only those jokes where such markers may be identified. To examine the status of these jokes scripts as manifestations of identity markers two questionnaires were created. For that reason, twelve jokes were selected, six per each questionnaire.

The questionnaires, the English translations of which are given in Appendices 2 and 3, are organized in three parts. The first five questions are demographic questions (gender, age, education, profession, and place of living). Questions 6-11 are based on jokes that represent the ethnic other in two roles, as a target (q6-q9) and as a joker (q10 and q11) followed by Linkert scale questions registering the degree to which respondents agree or disagree with the manner (the particular script by which) the ethnic other is presented in the joke. Question 12 is an open end question which asks respondents to provide a more elaborate answer on their responses to the previous questions. Questions 13 are 14 are based on experimentally designed jokes by manipulating the joke target. The original jokes have a target of the same ethnicity as the respondent, which in the questionnaire was replaced with a member of the other ethnic community. Thus, the two jokes originally targeting Macedonians were turned into jokes targeting Albanians and offered to Macedonian respondents. The same procedure was done with jokes targeting Albanians being replaced with Macedonians as joke targets and offered to Albanian respondents. While questions number 13 and 14 asked the respondents how much they agreed that the (manipulated) scripts are closely related to the target (the deliberately substituted one), question 15 asks the respondents to evaluate whether by changing the joke target (practically reverting the joke in its original form), the joke will make more sense.

The two questionnaires created by the use of Google forms platform were written in the mother tongue of the respondents and were posted online (links are provided in Appendices 2 and 3) in the period between April $3^{\text {st }}$ and April 17 $7^{\text {th }}$ 2017. Links to the questionnaires were posted on the Facebook pages of the South East European University, ${ }^{1}$ Facebook page of "Anketi" (surveys), ${ }^{2}$ and was additionally send to friends, family members, colleagues, with the request to forward it to their friends and colleagues. Initially more than 5000 people were targeted. However, the questionnaires were responded by a very low number of people (MK 
$=94 ; \mathrm{ALB}=24)$, a response rate indicative of the cultural and ethnic based willingness and habit of participation in any form of opinion survey.

\section{Making sense of the data: historic background and identification of ethnic scripts}

To facilitate readers' understanding of the joke selection and categorization processes that are studied here, and also of the responses by the respondents and the interviewees, a short account of place of ethnic Macedonians and ethnic Albanians in the nation formation period of the late $19^{\text {th }}$ and early $20^{\text {th }}$ century can help shed some light on the present day perceptions and predicaments held by the two communities.

Ill-fated Macedonia is the only current country in the Balkans which did not gain independence from the Ottoman Empire in $19^{\text {th }}$ or the early $20^{\text {th }}$ century. The historically most significant year for Macedonians - 1903 - witnessed an unsuccessful uprising against the Turks. The aftermath was devastating as many revolutionaries (komitadjis) were either captured by the retaliating Turks, hunted down by the interest-driven, Ottoman helping Bulgarians, or betrayed by Macedonian brethren. Ten years later, the ideal of free united Macedonia was completely crushed as a result of the two Balkan wars (1912 and 1913) and the resulting Bucharest Treaty from 1913 according to which the territories populated by Macedonians were divided between Greece, Bulgaria, and Serbia. This is the historic root of much of modern day anxiety among Macedonians themselves as well as of the antagonisms that exists between Macedonia and its neighbours. Indeed, despite Macedonia's 1991 independence from Yugoslavia, neighbouring countries have refused to recognize its national identity (language and history included). Instead, Macedonian national identity has been incessantly disputed, negated and made fun of by all its neighbours.

In Macedonia, the failure to establish a nation-state and unite its people and lands during the period of national formation, the accompanying sentiments of nostalgia for the loss of this national ideal of 'wholeness', and the continuously haunting feelings of brotherly betrayal and national divisions are all materially manifested across institutional (anthem, history), cultural (literature, music, art), and even banal (flags, postcards, key chains) national discourses. Fortunately or not, some of these culturally intimate dilemmas and anxieties are also encapsulated in present day ethnic humour about Macedonians, which the next section will show.

The Albanian ethnicity has experienced somewhat similar fate as Macedonians, since the territories populated by Albanians were divided between the Ottoman Empire, Serbia, and Montenegro with the 1878 Berlin Treaty. However, this did not discourage Albanians to continue their military actions (revolts and uprisings) mostly against the Ottoman rule, and to gradually succeed in creating a modern nation state of Albania in November 1912. The problem, however, was the Albanian population who stayed outside the borders of the new state, located in west Macedonia, Montenegro, and south Serbia (present day Kosovo). These territories, along with the population were integrated in Yugoslavia and a status as autonomous province was granted to Kosovo in 1974 only to be revoked in the early 80s. During the 80s, student protest in Kosovo took on nationalist overtones, which resulted in a harsh retaliation by Yugoslav authorities that included discriminatory policies and even military interventions. After the dissolution of Yugoslavia it was only matter of time before the Albanian nationalism repressed in Kosovo would transform into the Kosovo Liberation Army, which formed in 1996. The KLA waged a series of guerilla actions against the Yugoslav occupation. These actions gradually escalated into a full blown military conflict in 
1998-1999 (War of Kosovo). Ultimately, Kosovo gained its independence in 2007 with the huge support of US.

On one level, the social marginalization and segregation of ethnic Albanians, especially those who mostly lived in rural areas or were undereducated as a result of political oppression, was sufficient for them to be portrayed as backwards and stupid. Yet, on another level, popular discourses on ethnic Albanians' religiosity and of their devotion to family and ethnic group has combined with knowledge of the armed conflicts involving ethnic Albanians (from Ottoman, through Yugoslav to Serbian times) to construct social stereotypes of Albanians as aggressive, solidary, and temperamental members of a united community, as the humour material will show.

\section{Results}

\subsection{Jokes}

Having explained the joke collection and selection procedures, in this section I present the findings with some accompanying comments and additional explanations. The results are presented in Table 1 which shows the resources, the number of jokes collected and their categorization based on the script types identified.

Table 1. Jokes about Macedonians

\begin{tabular}{|c|c|c|}
\hline Resources & Functional ethnic scripts & Genuine ethnic scripts \\
\hline $\begin{array}{c}\text { Bulgarian sites } \\
(\mathrm{N}=165)\end{array}$ & Stupidity $(\mathrm{N}=15)$ & Language $(\mathrm{N}=45)$ \\
& Sexuality $(\mathrm{N}=12)$ & National identity $(\mathrm{N}=32)$ \\
& Laziness $(\mathrm{N}=3)$ & National history $(\mathrm{N}=24)$ \\
& Territorial size $(\mathrm{N}=5)$ & "The whole world is Macedonian" $(\mathrm{N}=18)$ \\
& $\begin{array}{c}\text { Other ethnic scripts: betrayal, cowardice, } \\
\text { "wholeness" nostalgia }(\mathrm{N}=11)\end{array}$ \\
\hline $\begin{array}{c}\text { Serbian sites } \\
(\mathrm{N}=23)\end{array}$ & Stupidity $(\mathrm{N}=5)$ & Language $(\mathrm{N}=15)$ \\
\hline $\begin{array}{c}\text { Macedonian } \\
\text { sites }(\mathrm{N}=68)\end{array}$ & Cunningness $(\mathrm{N}=57)$ & \\
& Self-disparagement $(\mathrm{N}=9)$ & \\
\hline
\end{tabular}

The majority of the jokes from the Bulgarian corpus ridicule the Macedonian language for being a Bulgarian dialect ("Why did the Bulgarian king Simeon and the Macedonian president manage to understand each other well? - Because they both speak broken Bulgarian"), or ridicule Macedonia(ns) for being Bulgaria(ns) as in "What do you get when a Macedonian takes a bath? - Pure Bulgarian!" The second most frequent group of jokes are those that ridicule and deny the existence of Macedonian history, such as "An announcement found in a Skopje [capital of Macedonia] book store: The History of Macedonia is out of stock, those interested in getting a copy may order it via SMS". Additionally, a smaller part of jokes tentatively classified as genuine ethnic jokes use the script "the whole world is Macedonia" to ridicule Macedonians' overblown feeling of global, pan-historic importance as in "Yuri Gagarin is the first Macedonian in the cosmos", or to target Macedonians for being traitors, cowards, and people obsessed with the dream of united Macedonia. Worth noting here is the fact that these scripts can equally be considered negative national 
stereotypes based on behavioural traits rather than distinctive and defining national attributes. In this respect, the analysis will try to demonstrate that these, otherwise general socially negative stereotypes may be brought to close relation to the ethnic identity of Macedonians. The three jokes from this group were selected for the questionnaire. They have the following scripts: betrayal, cowardice, and "wholeness nostalgia". The reasons for not including jokes that ridicule Macedonian history, language, or national identity in the questionnaire were to avoid insult and ridicule in the light of the fact that the examined population was Albanian, but also the personal belief that Albanians, regardless of their feeling for Macedonians are aware of the ethnic differences between Macedonian and Bulgarian national identities.

In the Serbian joke corpus, the majority of the jokes make fun of the Macedonian language, in particular, the post-positioned definite article occurring at the end of the nominal phrases, the Macedonian lexis for sounding funny, and the Macedonian linguistic ineptness to speak good Serbian. Due to their insult potential, these were not considered as proper material for further investigation (questionnaire). The other category of jokes, less in number, ridicule Macedonians for stupidity, poverty, dishonesty and the political situation they are in. Finally, as expected, the Macedonian joke corpus mostly represents the joke tellers as either superior or smarter, and better adapted (Hobbes) usually in multiethnic jokes. A smaller number of jokes present Macedonians as canny or self-pitying. The three jokes form this corpus selected for the questionnaire have the following scripts: canny/poor; ill wishing for the neighbour, and patriotism through malice.

Table 2. Jokes about Albanians

\begin{tabular}{|c|c|c|}
\hline Resources & Functional ethnic scripts & Genuine ethnic scripts \\
\hline $\begin{array}{c}\text { Macedonian sites } \\
(\mathrm{N}=15)\end{array}$ & Stupidity $(\mathrm{N}=9)$ & \\
& Politics $(\mathrm{N}=5)$ & \\
Religion $(\mathrm{N}=1)$ & Language $(\mathrm{N}=19)$ \\
\hline $\begin{array}{c}\text { Serbian sites } \\
(\mathrm{N}=40)\end{array}$ & $\begin{array}{c}\text { Attitude jokes }(\mathrm{N}=12) \\
\text { Poverty }(\mathrm{N}=9)\end{array}$ \\
\hline $\begin{array}{c}\text { Albanian sites } \\
(\mathrm{N}=58)\end{array}$ & Cunningness (27) & Aggression? $(\mathrm{N}=3)$ \\
& Stupidity (22) & Political sentiments? (N=4) \\
& Physical defect $(\mathrm{N}=2)$ & \\
\hline
\end{tabular}

The Albanian joke corpus differs in few significant aspects. First, unlike the Macedonian corpus, truly ethnic scripts are hard to identify. Those which come closest are from the Serbian resources, as the historically based antagonism between the two ethnicities is the strongest. However, this corpus mostly ridicules Albanians for their inability to pronounce the interdental / $1 /$ sound often softening it and pronouncing it as a palatal $/ 1 \mathrm{j} /$ sound. Since this ridicule and the attitude jokes they appear in are offensive to Albanians, these jokes were not used in the questionnaire. Therefore, the jokes used in the questionnaire are all from the Albanian corpus. Three of these jokes operate on universal joke scripts such as stupidity, canniness, and bad smell whereas the other three rely on the scripts of aggressive behaviour, interethnic relations, and political attitudes, which can equally be considered universal behavioural traits rather than ethnic attributes. However, the specific circumstances and relations that these scripts enact (relations to specific ethnic groups like Serbs, or specific political others like America) indicates that they might hold a deeper connection to ethnic identity and its perception when compared to scripts on stupidity or canniness. Some of the questions in the questionnaire were designed to test this hypothesis. 


\subsection{Questionnaires}

The results of the questionnaire are represented in the Table 3 bellow. For convenience the two answers on the left side of the Linkert scale spectrum ('completely agree' and 'agree') were merged into single category, represented here as 'agree'. The same was done with the values on the right side of the scale ('completely disagree' and 'disagree'). The middle column between Agree and Disagree represents the 'neither agree nor disagree' answers.

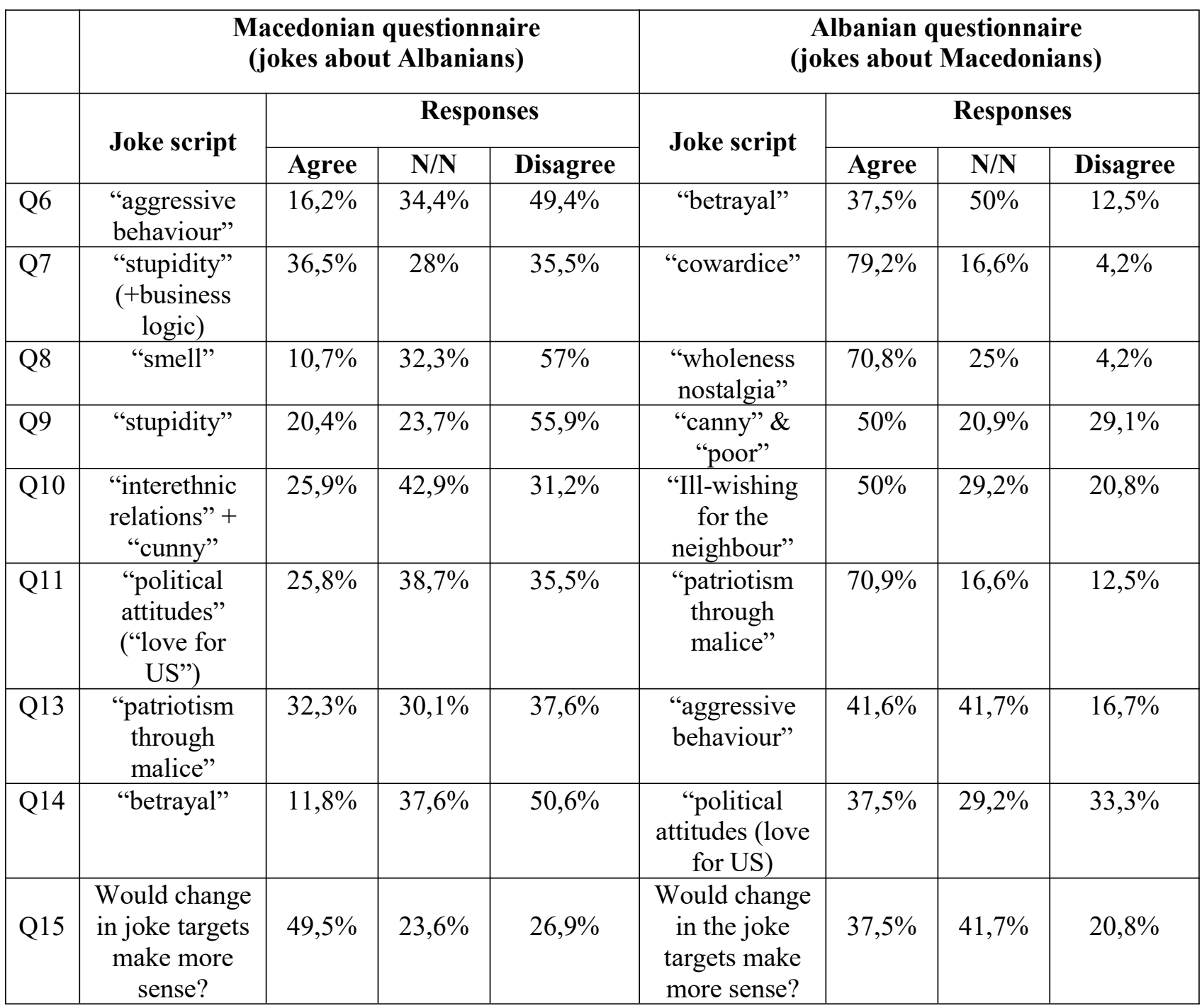

Although the results are self-evident, some comments are warranted. The results vary between those where the difference between the answers is large enough (the difference between percentage of respondents per answer is larger than $10 \%$ ) so the results can be taken as convincing evidence, albeit with certain reservations, that supports the (tentative) conclusions made, and those results upon which compelling conclusions cannot be made.

The answers to questions 6,8 and 9 belong to the first group. According to these, Macedonians tend to disagree with the image of Albanians as aggressive (q6), smelly (q8), or stupid (q9). Albeit the fact that half or slightly more than a half of the respondents disagree with this image, the results should be taken as indicating a tendency in a need of further investigation, rather than a trend or widespread opinion given the relative small number of tested subjects $(\mathrm{N}=94)$. On the other hand, it is difficult, if possible at all, to draw any plausible conclusions regarding respondents' reactions to the relation between Albanians and 
the scripts of stupidity (q7), canniness and interethnic conflict (q10), or political affiliations (q11) pinned on Albanians as the percentages of the answers are equally distributed along the three answers provided (agree, neither/nor, and disagree).

A similar impasse to the drawing of definite conclusions is shown in the respondents' divided opinion on the question whether Albanians manifest patriotism through malice towards the ethnic other (q13). The answers here are equally distributed among the three options $(32,3 \%, 30,1 \%$, and $37,6 \%)$. This is not the case with the script of betrayal, which Macedonian respondents find more unlikely to be pinned upon Albanians (50,6\% disagree). An almost equally high percentage $(49,5 \%)$ believe that the scripts of 'betrayal' and 'patriotism through malice' are more closely related to Macedonians rather than Albanians. Although the $49.5 \%$ of the respondents who believe that these scripts are more likely to be pinned to Macedonians is not very high it certainly suggests a more pronounced tendency and certainty in the opinion especially in the light of the $22 \%$ and $25 \%$ difference with the respondents who either disagree or does not agree or disagree.

To sum up, while answers to some questions $(7,10,11,13)$ are inconclusive and insufficient to establish a close relation between the scripts given and the perception of the ethnic group's identity, other questions $(6,8,9)$ more strongly suggest that respondents reject the close relation imputed between the scripts and the ethnic identity of the joke target. Interestingly the percentage allocation among all questions except the last, shows a slightly more pronounced tendency towards disagreement with joke scripts (questions 6, 7, 8, 9, 13, 14) or neither/nor attitude (questions 10, 11) with the smallest percentage falling on respondents who agreed with the image of Albanians presented in the jokes. For example, only $16,2 \%$ of the respondents agree that Albanians are aggressive, $10,7 \%$ that they are smelly, (q8) and 20,4\% that they are stupid (q9). This could be interpreted as a tendency to reject the relation between universal scripts such as stupidity and smell, on the one hand, and ethnicity, on the other. Finally, what came as an expected result is the recognition of a stronger and more convincing connection between the scripts of 'patriotism through malice' and 'betrayal' and Macedonian ethnic identity (q 15), a relation confirmed by the Albanian questionnaire.

The results of the questionnaire on jokes about Macedonians, which should be taken with a great grain of salt due to the low number of respondents $(\mathrm{N}=24)$, show quite a different tendency when it comes to answers' allocation per option and the percentage difference between answers. Unlike the trend of disagreeing with the image of Albanians created by the jokes used in the Macedonian questionnaire, the dominant tendency here is to agree with the image of Macedonians represented in the jokes. A significant part of the respondents agree that Macedonians are canny (q 9) having negative attitude towards the neighbours (q10), while the majority of them (70\% to $79 \%$ respectively) think of Macedonians as cowards (q 7), as being nostalgic for the loss of unity (q 8), and of manifesting patriotism through malice (q 11). These results are even more significant when one considers the low level of disagreement among respondents, at times as low as 4,2\% (q $7 \& 8$ ).

Unlike this high level of agreement in these case, which points to the perception of Macedonians in terms of the joke scripts used, no convincing relation between Macedonians and the scripts of 'betrayal' (q 6), 'aggressive behaviour' (q 13), and political affiliation (q 14) can be established due to equal distribution of answers among the three options. Similarly, a close connection between these scripts and Albanian ethnic identity cannot be established.

According to the mixed results, some scripts (aggression, political, affiliation, betrayal) do not relate to Macedonian ethnic identity as reflected in the Albanian perception of it, while other scripts, most notably patriotism through malice, wholeness nostalgia and cowardice are perceived as more closely related to Macedonian ethnic identity. 


\section{Discussion}

The collected material has revealed the existence of two types of ethnic humour according to the joke scripts used. The first type is the one already known throughout research literature, and which has been termed here as functional ethnic humour, one that targets universal human traits like stupidity, canniness, laziness, uncleanliness and so on in order to ridicule any ethnic group. The second type of humour is what I have called genuine ethnic humour, within which one can differentiate between two (sub) types of ethnic humour. The first type is a truly genuine ethnic humour one that relies on joke scripts that target ethnic identity markers like history, language, and traditions that are specific to a particular ethnicity. In this respect, quite a few instances of such joke script have been identified in the present corpus.

Thus, within the corpus containing jokes on Macedonians $(\mathrm{N}=256)$, the Bulgarian part contains the greatest number of truly ethnic jokes $(\mathrm{N}=101)$. As the analysis has shown, these jokes target, ridicule, and even negate ethnically defining markers such as the Macedonian national language, national identity, and national history. The humour presented in these jokes, which work to negate Macedonian ethnic identity, accomplished through assimilation of ethnical attributes (e.g., "Macedonian language is broken dialect of Bulgarian", "Macedonians are but dirty Bulgarians"), is contingent on genuine historic antagonisms between the two countries. At the same time, such humour also conforms to the contemporary discourses, both institutional and popular, that are produced in Bulgaria on Macedonia. For example, the official position of the Republic of Bulgaria is that the Macedonian language is a Bulgarian dialect. Similarly Bulgarian historiographies typically claim that many of the core figures of Macedonian national history, such as Goce Delcev, a fin-de-siècle revolutionary, Vojdan Cerndrrinski, a playwright, and Marko Cepenkov, a folklorist, are of Bulgarian origin. The antagonism and contestation present in these discourses only confirm that the joke lore is also of the same ethnically idiosyncratic nature.

The Serbian joke lore also contains samples of genuine ethnic jokes, although to a much lesser degree $(\mathrm{N}=15)$. Unlike Bulgarian joke lore the focus of these jokes is on a singular ethnic attribute, the national language. The fact that this humour targets idiosyncratic linguistic forms and structures (post-positioned article and lexis) evidences its true ethnic nature. On the other hand, the evidently lesser scope of such instances when compared to the Bulgarian corpus, is due to different political and historic circumstances between the two ethnicities (Macedonian and Serbian). This may be due to the common Yugoslav history the two nations have shared and the relative lack of deeper historical antagonism. This mitigated form of antagonism is reflected in how Serbian jokes ridicule the Macedonian language. It is not denigrated as a Serbian dialect; rather, jokes target the language's morpho-lexical structure. This is quite different than the tendency of much western European and American ethnic humour, which makes fun of the linguistic ineptness of foreign speakers. Although both types of humour on language are derogative, it is only the former that makes fun of genuine ethnic markers - the mother tongue.

The second type of quasi-ethnic humour, I would say, is the one that relies on jokes scripts that are less specific in ethnic terms, such as cowardice, betrayal, wholeness nostalgia, aggression or political inclination. These traits are definitely not ethnic markers as many ethnicities or any social group may be pinned down with these attributes, but nonetheless these may be 'ethnicised', that is brought in closer connection to one rather than another ethnicity. Macedonian history, and folklore for one, include several instances of betrayal, for example, among fin-de-siècles revolutionaries such as Goce Delcev, Jane Sandanski, and Pere Tosev. These infamous historic events have remained a significant part of the popular ethnic discourses about and perceptions of Macedonians. The relation between general behavioral traits like cowardice, betrayal, nostalgia, and Macedonians, is partly hinted by the 
results of the Albanian questionnaire where these scripts are seen as related to Macedonian ethnic identity, an opinion additionally suggested by the results of the Macedonian questionnaire (question 15 in particular). The relation between these attributes and Macedonian ethnic identity is further corroborated by previous research (Takovski 2015:143144) which shows that Macedonians both recognize and accept these same qualities to be constitutive element of their ethnic identity. However, in lack of strong empirical evidence validated by a significant number of test subjects these assumptions can only serve as a starting point for future research.

While the content analysis of the joke material undeniably reveals the existence of truly ethnic humour, that is, humour that targets idiosyncratic, defining elements of ethnic identity, the results of the survey only indicate tendencies that need further exploration. The survey conducted with Macedonians suggest that respondents are more likely to reject certain universal scripts (stupidity; smell) as ethnically non-related, while the survey conducted with Albanians more strongly indicate perception of Macedonians in terms of attributes that are not identity markers per se, but that can be conceived as connected to ethnic identity. To falsify or prove the assumption that some scripts can be ethnicised (related more closely to one ethnicity) further investigation needs to be made in order to provide more convincing empirical evidence. This I believe would best be done with strong institutional support since individual research risks confronting again people's reluctance to participate in a survey.

Finally, unlike the Macedonian joke corpus, the Albanian joke corpus confirms the assumption that ethnic humour ridicules the ethnic other for being stupid, canny, unclean and so on, as samples from the Macedonian and Albanian resources show. Somewhat different are the samples from the Serbian corpus of ethnic jokes on Albanians which ridicule the Albanians for being inept speakers of Serbian language, but again mastery of foreign language is ethnically non-specific. The reason why this corpus confirms to the ethnic humour theory is perhaps the sociopolitical relations between Macedonians and Serbs on one hand as the dominant social ethnic group in their states, and the Albanians as ethnic minority in those societies which needed to regulate ethnic based hierarchies through humour.

\section{Conclusion}

There is little doubt that much of ethnic humour comprises of jokes that ridicule various ethnicities by using non-ethnic joke scripts in order to perpetuate ethnic based hierarchies in modern industrial societies, or to express we-ness through communal laughter. But this is not the whole of ethnic humour throughout the world, as there are societies which do not share the same socioeconomic (industrialisation and migration) and historic circumstances as the western societies, neither do they share the same ethnic humour. In this respect, this study tried to offer and discuss a different type of ethnic humour, one that is based on what I have called genuine ethnic joke scripts due to their close relation to ethnic identity and its markers. In so doing, the study argued that such jokes serve the purpose of expressing inter-ethnic contestation, even negation, and most importantly, of marking boundaries around specific identity contents/markers. In this way, such jokes do not conform to the dominant function ascribed to them by ethnic humour theory, that is, to perpetuate ethnic based hierarches. Therefore, such jokes may be considered a different, more genuine ethnic jokes than those already studied. In addition, the study has revealed some future research potential regarding joke material that relies not on ethnically specific scripts, but on a more general ones like cowardice, betrayal, and so forth, which nonetheless can be linked to one interethnic context rather than another, since they capture specific, historically supported ethnic anxieties and conflicts. Although there is potential to this hypothesis, there is also much work to be done 
hin order to plausibly confirm these assumptions. Finally, one should also consider the possibility that genuine ethnic humour may not be identified in all contexts involving interethnic antagonism, as the antagonism may be expressed in a different manner. In the light of this, the Bulgarian material is abundant with samples of genuine ethnic humour on Macedonians. Additionally, Greek material, due to the linguistic barrier was not considered in the study, nor was material from elsewhere in the Balkans. Extending the scope of study will most certainly shed more light on the phenomena of genuine ethnic humour. This should only encourage further investigation and research on joke material from contexts that exhibit different socio-historic and political circumstances compared to humour research focused on the industrialised West. Such research can only contribute to better understanding of ethnic humour across societies.

\section{Acknowledgements}

The author would like to express his gratitude to Lear Cilku and Guxim Nuhiu, the two informants without whose help the collection of the Albanian joke corpora would have been impossible. Additionally, many thanks to all the focus group participants who were willing to contribute to this research.

\section{Notes}

${ }^{1}$ See https://www.facebook.com/pg/SEEUniversity/community/?ref=page internal. The webpage has 62163 followers and 2500 members.

${ }^{2}$ See https://www.facebook.com/groups/741460502628931/members/.

The webpage has 983 members.

\section{Appendix}

Appendix 1. List of Internet resources.

Bulgarian sites
a. http://vic-bg.com/
b. http://www.vicove.biz/makedoniya
c. http://clubs.dir.bg/showflat.php?Board=maked\&Number $=1942728179 \&$ page $=\& v i$ $\mathrm{ew}=\& \mathrm{sb}=\& p a r t=a l l \& v c=1$
d. http://bkks.org/forum/index.php?topic $=1814.0$

Serbian sites

a. http://www.balkanvicevi.com/vicevi-o-makedoncima

b. https://www.erepublik.com/en/article/vicevi-o-hrvatima-crnogorcima-bosancimaslovencima-i-makedoncima-905822/1/20

c. http://mail.vicevi.net/

d. http://www.duhoviti.com/razno/vicevi-o-albancima-siptarima.html http://srpskatrobojka.zikforum.com/t369-vicevi-o-albancima http://www.autentik.net/forum/index.php?topic=5297.0 
Macedonian sites
a. http://www.vicoteka.mk/vicovi/si-bile/page/2/
b. http://www.vicoteka.mk
c. http://www.vicoteka.mk

Albanian sites

a. http://qesh-se-eshte-falas.weebly.com/barcoleta.html ;

b. http://www.barcaletashqip.com/08/2009/derri-amerikani-anglezi-dhe-shqiptari/; https://jtf.org/forum/index.php?topic=39281.0.

Appendix 2. Macedonian questionnaire

https://docs.google.com/forms/d/e/1FAIpQLSdJkSThPkRFABrhgIfybPAt1SWmG1StB0F2NA M1w36gOnuF0w/viewform?usp=sf link

Part 1. Demographic data

Gender: a) male $\quad$ b) female
Age:
a) under 18
b) $18-25$
c) $25-40$
d) $40-60$
e) $60+$

Education: a) primary school $\quad$ b) secondary school c) university $\quad$ d) $\mathrm{MA} / \mathrm{PhD}$

Profession:

Residence:

Part 2. Ethnic jokes and questions

6. An American, German and Albanian visit their French host who takes them on a walk through Paris to show them the most famous tourist sites. The last to visit was the Eiffel Tower. After explaining its history the host asked if there are any questions:

- How much did the tower cost? - asks the American.

- How many tons of iron were used to build it? - asks the German.

- How many tones of dynamite does it take to blow it? - asks the Albanian.

The jokes represents Albanians as prone to destruction and explosion. How much do you agree with the image? disagree
a) fully agree
b) agree
c) neither agree nor disagree
d) disagree
e) completely

7. An Albanian form Gostivar [west Macedonian town] went on a vacation in Croatia. After finding accommodation, he went to the beach, saw the see and chuted out in excitement:

"Wow, imagine how much lemonade you can make with this water". 
The joke creates and image of Albanians as slightly stupid but also canny at the same time as they seek profit opportunity while on vacation. How much do you agree?
a) fully agree
b) agree
c) neither agree nor disagree
d) disagree
e) completely disagree

8. American, English and Albanian were competing for the king of Zimbabwe's daughter. The winner is the one who spends most time with a pig in its house.

American enters first, after half an hour later comes out complaining not being able to endure. The English goes in second and after an hour also leaves complaining about the smell. The last to enter was the Albanian, and stays there for one hour, two, three, after which the pig comes out saying:

"I can't make it any more.

The joke depicts Albanians as smelly. How much do you agree with the idea? disagree
a) fully agree
b) agree
c) neither agree nor disagree
d) disagree
e) completely

9. Albanian and American were sitting in the local bar. The waiter comes asking the American what he would like to drink. The American replies "Johny Walker, whiskey". The Albanian thinking it is his turn to introduce himself while also placing order says. Shaban, Coca Cola.

To what degree do you agree with the idea of Albanian being stupid?
a) fully agree
b) agree
c) neither agree nor disagree
d) disagree
e) completely disagree

10. A policeman stops an Albanian wearing on his head a Serbian hat with typical nationalist Serbian insignia (a two-headed eagle with the four $S$ cross) and asks him what is that:

"That, my dear officer is back protection!", answers the Albanian.

What do you mean back support?, asks the Serbian police officer.

It's simple, after I started wearing it, my back does not hurt (implying that he is mistaken for a Serb and not beaten any longer).

The jokes creates an image of the Albanian as a canny person who would 'mask' himeslef as a member of the ethnicity that stereotypically hates his own ethnicity only to avoid getting beaten? To what extent do you agree? disagree
a) fully agree
b) agree
c) neither agree nor disagree
d) disagree
e) completely

11. "Love thy country as the Albanian loves America”.

The joke suggests that there is a strong bond and inclination of Albanians towards America. How much do you agree with the idea? disagree
a) fully agree
b) agree
c) neither agree nor disagree
d) disagree
e) completely

12. If your answer to any of the previous six questions (6-11) was either disagree or completely disagree please give a more detailed explanation of your answer.

13. Albanian, American, German and Serb are sitting on the edge of a skyscraper. 
- For America! - said the American, jumped and died.

- For Germany! - said the German, jumped and died.

- For Albania! - said the Albanian and pushes the Serb.

In the joke the Albanian is presented as someone who expresses his patriotic feelings thorugh an act of malice towards the other rather than self-sacrifice. How much do you agree? disagree
a) fully agree
b) agree
c) neither agree nor disagree
d) disagree
e) completely

14. What is a single Albanian? - A ballista [Albanian freedom fighter].

How about two Albanians - A commander/chief and a ballista.

And three Albanians? - A commander, a ballista and a traitor.

The joke gives an image of Albanians as traitors. To what extent do you agree with the image? disagree
a) fully agree
b) agree
c) neither agree nor disagree
d) disagree
e) completely

15. If you substitute the joke targets in the previous two jokes (to replace Albanian with a Macedonian) would the jokes make more sense??
a) yes
b) I don't know
c) no

Appendix 3. Albanian questionnaire

https://docs.google.com/forms/d/e/1FAIpQLSdQk-ZzSxyRF85ABZ1GFQ1IwRjEF1JIdZ9uZQvLrLtEKc3KA/viewform?usp=sf link

The first five questions are identical as in the Macedonian questionnaire.

6. What is a single Macedonian? - A leader.

How about two Macedonians - A leader and a komitaji [freedom fighter].

And three Macedonians? - A leader, a komitaji and a traitor.

The joke gives an image of Macedonians as traitors. To what extent do you agree with the image? disagree
a) fully agree
b) agree
c) neither agree nor disagree
d) disagree
e) completely

7. Macedonian posse of Macedonian komitajis was fighting against the Ottoman army. After a while the Turks received a back up. One of the komitajis asked his leader:

-Dear leader, there are quite many Turks. Do we continue the fight or do we surrender? -A Macedonian komitaji never surrenders, he runs.

In the joke the Macedonians are represented as cowards. How much do you agree? disagree
a) fully agree
b) agree
c) neither agree nor disagree
d) disagree
e) completely 
8. In 1969 when the Americans stepped on the Moon, thousand Macedonian komitajis looked up to to the Moon and said: "Moon, you land of Macedonia, one they we shall set you free"

The joke represents Macedonians as obsessed with liberating imaginary territories that they believe is theirs, thus referring to their nostalgia for the loss of the united Macedonia. To what extent do you agree with this idea? disagree
a) fully agree
b) agree
c) neither agree nor disagree
d) disagree
e) completely

9. French, German and Macedonian were talking. The French says: "Each morning I make two eggs sunny side up, get into the car, and go to work.". The German continues: "I also make two eggs and a sausage, get into my car and off I go to work." The Macedonian then says: "Each morning I put my own eggs [testicles] on my bike and straight to work."

The joke portrays Macedonians as canny. How much do you agree? disagree
a) fully agree
b) agree
c) neither agree nor disagree
d) disagree
e) completely

10. Macedonian, Serb and a Greek caught a goldfish. The fish tells them that she will grant them all a single wish if they let her go. They all agreed.

The Serb: "I want every Serb to be rich".

"Done", says the goldfish.

The Greek: "I want a wall around the country because I can't stand looking at our neighbours"

"The wall is already there", replies the fish.

Then the Macedonian asks the gold fish if the wall is waterproof, and when hearing that it is he just says:

"Fill it in".

While the Serb wishes well for its kin, the Greek wants clear demarcation, the Macedonian is partly as canny, but also as malicious, especially towards the Greek. How much do you agree with this assumption?
a) fully agree
b) agree
c) neither agree nor disagree
d) disagree
e) completely

11. Macedonian, American, German and a Greek are sitting on the edge of a skyscraper.

- For America! - said the American, jumped and died.

- For Germany! - said the German, jumped and died.

- For Macedonia! - said the Macedonian and pushed the Greek.

In the joke the Macedonian is presented as someone who expresses his patriotic feelings thorough an act of malice towards the other rather than self-sacrifice. How much do you agree?
a) fully agree
b) agree
c) neither agree nor disagree
d) disagree
e) completely

12. If your answer to any of the previous six questions (6-11) was either disagree or completely disagree please give a more detailed explanation of your answer. 
13. An American, German and Macedonian visit their French host who takes them on a walk through Paris to show them the most famous tourist sites. The last to visit was the Eiffel Tower. After explaining its history the host asked if there are any questions:

- How much did the tower cost? - asks the American.

- How many tons of iron were used to build it? - asks the German.

- How many tones of dynamite does it take to blow it? - asks the Macedonian.

The jokes represents Macedonians as prone to destruction and explosion [prone to aggression]. How much do you agree with the image? disagree
a) fully agree
b) agree
c) neither agree nor disagree
d) disagree
e) completely

14. "Love thy country as the Macedonian loves America".

The joke suggests that there is a strong bond and inclination of Macedonians towards America. How much do you agree with the idea? disagree
a) fully agree
b) agree
c) neither agree nor disagree
d) disagree
e) completely

15. If you substitute the joke targets in the previous two jokes (to replace Macedonian with a Albanian) would the jokes make more sense??
a) yes
b) I don't know
c) no

\section{References}

Apte M. (1985). Humour and Laughter: An Anthropological Approach. Ithaca: Cornell University Press.

Apte, M. (1987). 'Ethnic humour versus sense of humour: An American sociocultural dilemma'. American Behavioural Scientist 30 (3), pp. 27-41.

Barth, F. (1969). Ethnic Groups and Boundaries: The Social Organisation of Culture Difference. Boston: Little, Brown, \& Co.

Brass, P. R. (1991). Ethnicity and Nationalism: Theory and Comparison. New Delhi, Newbury Park, CA: Sage Publications.

Boskin, J. \& Dorinson, J. (1985). 'Ethnic humour: subversion and survival'. American Quarterly 37 (1), pp. 81-97.

Boxman, L. S. \& Shifman, L. 2015. 'When ethnic humour goes digital'. New Media and Society 17(4), pp. 520-539.

Cohen, A. (1996). 'Ethnicity and politics', in Hutchinson, J. \& Smith, D.C (eds.), Ethnicity. Oxford: Oxford University Press, pp. 83-84

Cundall, M. (2012). 'Towards better understanding of racist and ethnic humour'. Humour: International Journal of Humour Research 25 (2), pp. 155-177.

Davies, C. (1990). Ethnic Humour Around the World: A Comparative Analysis. Bloomington: Indiana University Press.

Davies, C. (1998). The Mirth of Nations. New Brunswick, NJ: Transaction.

del Rio, C.M. (2013). 'Can ethnic humour appreciation be influenced by political reasons? A 
comparative study of the Basque Country and Catalonia'. European Journal of Humour Research 1(2), pp. 24- 42.

Geertz, C. (1963). 'The integrative revolution: primordial sentiments and civil politics in the new states', in Geertz, C. (ed.), Old Societies and New States: The Quest for Modernity in Asia and Africa. New York: Free Press, pp. 255-310.

Genova, D. (2011). Studying Humour Seriously. Veliko Turnovo: Faber.

Genova, D. (2014). 'Ethnic and self-reflexive humour in Bulgaria', In Науковий Вісник Чернівецького університету. Германська філологія, рр. 180-195.

Gonzales, M. E. \& Wiseman, R. L. (2005). 'Ethnic identification and the perceived humour and rudeness of ethnic jokes'. Intercultural Communication Studies 14 (2), pp. $170-183$.

Hechter, M. ( 1986 ). 'A rational choice approach to race and ethnic relations', in Mason, D \&

Rex, J. (eds.), Theories of Race and Ethnic Relations. Cambridge: Cambridge University Press, pp. 268-277.

Kuipers, G. (2000). 'The difference between a Surinamese and a Turk: Ethnic jokes and the position of ethnic minorities in the Netherlands'. Humour: International Journal of Humour Research 13 (2), pp. 141-175.

Kuipers, G. \& van der Ent, B. (2016). 'The seriousness of ethnic jokes: Ethnic humour and social change in the Netherlands, 1995-2012'. Humour: International Journal of Humour Research 29(4), pp. 605-633.

Laineste, L. (2005). 'Targets of Estonian ethnic jokes within the theory of ethnic humour (C. Davies)'. Folklore 29, pp. 7-24. Available at: http://www.folklore.ee/folklore/vol29/davies.pdf.

Lowe, J. 1986. 'Theories of ethnic humour: How to enter, laughing'. American Quarterly 38 (3), pp. 439-460.

Martin, R.A. (2006). The Psychology of Humour: An Integrative Approach. Burlington: Elsevier

Academic Press.

Martineau, W.H. (1972). 'A model of the social functions of humour', In J. H. Goldstein, \& P. E. McGhee (eds.), The Psychology of Humour. New York: Academic Press, pp. 101-125.

Oshima, K. (2000). 'Ethnic jokes and social function in Hawaii'. Humour: International Journal of Humour Research 13 (1), pp. 41-57.

Popescu, C. (2011). 'Understanding ethnic humour in Romanian jokes'. In Dynel, M. (ed.), The Pragmatics of Humour across Discourse Domains. Amsterdam/Philadelphia: John Benjamins Publishing Company, pp.173-190.

Rappoport, L. (2005). Punchlines: The Case for Racial, Ethnic, and Gender Humour. Westport, CT: Praeger Publishers.

Schutz, C. (1977). Political Humour. Cranbury, N. J.: Associated University Presses.

Schutz, C. (1989). 'The sociability of ethnic jokes'. Humour: International Journal of Humour Research 2 (2), pp. 165-177.

Smith, D. A. (1986). The Ethnic Origins of Nations. Oxford: Blackwell.

Smith, D. A. (1991). National Identity. Hardmondsworth: Penguin Books.

Sollors, W. (1986). Beyond Ethnicity: Consent and Descent in American Culture. New York: Oxford University Press.

Takovski, A. (2015). 'From joker to the butt and back: Ethnic identity construction through humour', Language and Dialogue 5 (1), pp. 127-150.

van der Berghe, P.L. (1995). 'Does race matter?', Nations and Nationalisms 1(3), pp. 357-368. Weaver, S. (2014). 'Ethnicity and humour', in Attardo, S. (ed.), Encyclopedia of Humour Studies. (Vols. 1-2). Thousand Oaks, California: Sage Publications., pp. 81. 